\title{
Fumigant and feeding deterrent activity of essential oils against Cryptolestes ferrugineus (Stephens) (Coleoptera: Laemophloeidae)
}

\author{
SILVI IKAWATI ${ }^{1,2, \boldsymbol{v}}$, TOTO HIMAWAN ${ }^{2}$, ABDUL LATIEF ABADI $^{2}$, HAGUS TARNO ${ }^{2}$ \\ ${ }^{1}$ Graduate Program, Faculty of Agriculture, Universitas Brawijaya. Jl. Veteran, Malang 65145, East Java, Indonesia \\ ${ }^{2}$ Department of Plant Pest and Disease, Faculty of Agriculture, Universitas Brawijaya. Jl. Veteran, Malang 65145, East Java, Indonesia. \\ Tel.: +62-341-551665, 565845, Fax.: +62-341-560011, ^email: silviikawati@ub.ac.id
}

Manuscript received: 26 July 2020. Revision accepted: 25 August 2020.

\begin{abstract}
Ikawati S, Himawan T, Abadi AL, Tarno H. 2020. Fumigant and feeding deterrent activity of essential oils against Cryptolestes ferrugineus (Stephens) (Coleoptera: Laemophloeidae). Biodiversitas 21: 4301-4308. This study aimed to determine the fumigant and antifeedant activity of some plant essential oils against Cryptolestes ferrugineus. Essential oils were extracted from cinnamon (Cinnamomum verum), kaffir lime (Citrus hystrix), citronella grass (Cymbopogon nardus), zodea (Euodia suaveolens), and clove (Syzygium aromaticum). The extraction used the maceration method with $n$-Hexane as a solvent. The results of the experiments showed that all essential oils have fumigant toxicity. Fumigant toxicity of kaffir lime, citronella grass, zodea, and clove oil; eggs and pupae were more susceptible than adults and larvae, while for cinnamon, pupae and adults were more susceptible than eggs and larvae. Median Lethal Concentration (LC50) of all essential oils for eggs larvae, pupae, and adults respectively, for cinnamon were 17, 24, 9, and $12 \mathrm{ppm}$, for kaffir lime were 12,17, 8 and $15 \mathrm{ppm}$, however, on citronella grass were 11, 22, 8, and 14 ppm, for zodea were 16, 22, 10 and $20 \mathrm{ppm}$, for clove were 11, 24, 7 and $14 \mathrm{ppm}$. The fifth essential oils showed antifeedant activity in a no-choice test against $C$. ferrugineus adults. Also, the fifth essential oils significantly reduced the relative growth rate (RGR), relative consumption rate (RCR), and food utilization (ECI) of $C$. ferrugineus adults. It shows that the essential oils have great potential as one of the storage pest control components.
\end{abstract}

Keywords: Botanical insecticide, Cryptolestes ferrugineus, essential oil, feeding deterrent activity, fumigant toxicity

\section{INTRODUCTION}

Rusty grain beetle, Cryptolestes ferrugineus, is a common beetle pest of stored grain. This insect pest is present worldwide (Tay et al. 2016). Cryptolestes insects are a secondary pest, which benefits from grains previously damaged by a primary pest. Various control measures against storage pests can be applied, including physical control, chemical control, biocontrol, botanical insecticides, natural protein, and others (Boyer et al. 2012). In the case of stored product pests, control, which is frequently used, are synthetic insecticide.

Phosphine gas (PH3) and methyl bromide (Rajendran and Sriranjini 2008) are the two commonly used fumigant for stored product protection worldwide. Widespread use of synthetic insecticides in agriculture has ecotoxicological, environmental, and social consequences (Campolo et al. 2018). Synthetic chemical use could result in environmental health risks and pest resistance. The development of resistance to phosphine in C. Ferrugineus has occurred (Jagadeesan et al. 2016). For methyl bromide, which is a broad-spectrum fumigant, has been declared as the ozone-depleting substances and, therefore, has banned its use (Rajendran and Sriranjini 2008). Alternatives to conventional fumigants and contact insecticides are needed because many are being banned from the market (Hasan et al. 2020). Essential oils are aromatic liquids with specific volatile odor or flavor, and a combination of benzene derivatives, terpenes various hydrocarbons and straight- chain compounds (Upadhyay 2010). Ability insecticide plant essential oils that are contact and fumigant have been widely demonstrated against stored product pests. However, few have seen its effect on $C$. ferrugineus.

Storage pest control with essential oils as botanical insecticides may provide multiple mechanisms of action. Such compounds can act as a fumigant, contact insecticide, antifeedant, and as a repellent (Descamps et al. 2011; Germinara et al. 2017), and also may result in some biological parameters such as reproduction and effects on in enzymes activity (Kiran et al. 2017). Fumigation and repellent activity plays a major role in controlling insect pests in stored products. Stored-product insects varied in their susceptibility to plant compounds (Rajendran and Sriranjini 2008).

Essential oils are produced by 17,500 higher plant aromatic species in a few families, including Myrtaceae, Lauraceae, Lamiaceae, and Asteraceae. Depending on the plant species considered, essential oils are stored in various plant organs, such as flowers, leaves, wood, roots, rhizomes, fruits, and seeds (Regnault-Roger et al. 2012). The plants used in this study were cinnamon bark (Cinnamomum verum), kaffir lime leaves (Citrus hystrix), leaves of citronella grass (Cymbopogon nardus), leaves of zodea (Euodia suaveolens), and leaves of clove (Syzygium aromaticum). Some authors attributed the ability of these kinds of essential oils to storage pests (Doumbia et al. 2014; Correa et al. 2015; Cameron et al. 2016; Ikawati et al. 2017). The first aim of this study was to determine the 
fumigant toxicity of several plant essential oils, which tested at four development stages of Cryptolestes ferrugineus. The second aim was to determine antifeedant activity essential oils against adults of $C$. ferrugineus.

\section{MATERIALS AND METHODS}

\section{Insects}

Insects of $C$. ferrugineus Indonesia strain adult obtained from the laboratory of entomology, Faculty of Agriculture, University of Brawijaya Malang, Indonesia. Insects were breed in glass jars (5 liters) containing $500 \mathrm{~g}$ rice and yeast (ratio 95\%: 5\%) and covered with gauze for ventilation. Insects are maintained in laboratory conditions (temperature $27 \pm 2{ }^{\circ} \mathrm{C}$ and relative humidity of $70 \% \pm 5 \%$ ) and without insecticide treatment for several generations. All experimental procedures were performed under the same environmental conditions. The eggs were collected on pleated black filter papers by placing adults on the filters in a bowl half-filled with rice for $48 \mathrm{~h}$. To avoid contamination of other organisms, they then performed the sterilization of feed. Rice sterilized by cooled at $-15^{\circ} \mathrm{C}$ for a week. The rice used is IR 64 rice varieties.

\section{Plant extraction}

Plants that be extracted were bark of cinnamon (Cinnamomum verum), leaves of kaffir lime (Citrus hystrix), leaves of citronella grass (Cymbopogon nardus), leaves of zodea (Euodia suaveolens), and leaves of clove (Syzygium aromaticum). Extraction followed according to the method of Ikawati et al. (2017). Plants treatment before extraction is withering with dried at room temperature for 24 hours. The purpose of withering material is to reduce the water content, so expect the extraction takes place faster and more durable against microbes. Materials that have been withered cut into small pieces to open the volatile oil glands so that samples can accelerate the process of extraction. Maceration method with n-Hexane as a solvent. Maceration was performed with samples and a solvent ratio of 1: 4. The used solvent was n-Hexane $96 \%$. Maceration used stirring shaker at $120 \mathrm{rpm}$ for 24 hours. Then, separation of n-Hexane using a rotary vacuum evaporator. Evaporator temperature is set around $60^{\circ} \mathrm{C}$ and then essential oils stored in refrigerator $4^{\circ} \mathrm{C}$.

\section{Gas chromatography/mass spectrometry}

Oil composition was analyzed by gas chromatographymass spectrometry (GC-MS) (Shimadzu, Japan). GCMS analysis under the following conditions: Capillary column (30m length x $0.25 \mathrm{~mm}$ ID x $0.25 \mu \mathrm{m}$ film thickness); Helium Carrier Gas (1.34 mL/minute); $250^{\circ} \mathrm{C}$ injector temperature; $240^{\circ} \mathrm{C}$ interface temperature; $200^{\circ} \mathrm{C}$ Ion Source Temperature; column temperature programmed at $60^{\circ} \mathrm{C}$ with $10^{\circ} \mathrm{C} /$ minute rise to $230^{\circ} \mathrm{C}$. The components were identified based on a comparison of the retention times with computer matching spectral MS data against Wiley 8.

\section{Fumigant toxicity assay}

The method followed Ikawati et al. (2017), for larvae, pupae and adults fumigant activity assay carried out by exposing 30 larvae (age 10-12 days), 30 pupae (aged 1-2 days) and 20 adults (aged 5-7 days) of C. Ferrugineus (without distinction of male and female). This assay was conducted in a $250 \mathrm{~mL}$ glass flask, which was closed using rubber cover. The concentration used for essential oil tested are $0 \mathrm{~mL}, 1,25 \mathrm{~mL}, 2,5 \mathrm{~mL}, 5 \mathrm{~mL}$ dan $10 \mathrm{~mL}$ were dissolved in $1 \mathrm{~mL}$ of acetone. Each of these concentrations dropped evenly on a piece of Whatman No one filter paper $(7 \mathrm{~cm} \mathrm{x} 9 \mathrm{~cm})$ and air-dried for 10 minutes, and then one side is attached to the rubber. Filter paper attached such that it did not in contact with the walls of the flask. After that, the flask is kept in an incubator at a temperature of $27^{\circ} \mathrm{C}$ and $75 \% \mathrm{Rh}$. Each treatment was repeated five times. After exposure for 48 hours, respectively (larva, pupa, and adult) transferred into the Petri dish and mortality of larvae and adults be observed. The insects are considered dead when touched and do not show movement. Pupae were observed daily for ten days, and emerging adults were recorded, and pupae not reach adult stage was considered dead.

Fumigant activity assay against eggs was carried out by exposure to the eggs (age 0-24 hours). Eggs laid on round cloning plate. Each cloning plate is composed of 20 microwell plate (Each microwell filled one egg, each replication used as many as 20 eggs. The plate which had been containing eggs stored in $750 \mathrm{~mL}$ jar. Furthermore, the procedures for such treatment steps on the previous treatment. After 48 hours, the plate was transferred to the maintenance. Observations on hatching eggs carried out every day under a stereo microscope for ten days and eggs that did not hatch considered dead. Each treatment was repeated five times.

If there is the death of the C.ferrugineus insect in control, the correction percentage calculation is calculated based on the Abbott formula (Abbott 1925).

$$
P=\frac{X-Y}{X} \times 100
$$

Where: $P$ is the percentage of corrected mortality of $C$. ferrugineus insect, $X$ is the percentage of $C$. ferrugineus insects live at the control, $Y$ is the percentage of insects that live on treatment.

\section{Nutritional indices and antifeeding activity assay}

Flour disks were prepared according to the method of Huang and Ho (1998) with some modifications. Two hundred microlitres of a stirred suspension of wheat flour in water $(0.2 \mathrm{~g} / \mathrm{mL})$ were pipetted onto a plastic Petri dish to form disks. The disks were left in the fume cupboard overnight to dry. They were then equilibrated at $30 \pm 1^{\circ} \mathrm{C}$ and $70-80 \%$ r.h. for 48 h. Each flour disk weighed between 27 to $30 \mathrm{mg}$, and its moisture content was $13.5 \pm 0.1 \%$. 
Flour disks were individually treated with aliquots of 5 $\mu \mathrm{L}$ of various concentrations of the essential oils, and water was used in controls. The solvent was allowed to evaporate for one $\mathrm{h}$, and the disks were then placed individually in glass vials (diameter $2.5 \mathrm{~cm}$, height $5.5 \mathrm{~cm}$ ) for weighing. In a no-choice test, a group of 10 unsexed adults was added to each vial containing the disks. One or two flour disks were given to $C$. ferruginous. Each of these vials was weighed and left in the incubator. After three days, the weights of the flour disks and live insects were then weighed again with any mortality of insects recorded. Glass vials containing treated flour disks but without insects were prepared to determine any decrease in weights due to evaporation of water and essential oil. Treatment was repeated five times. For nutritional indices and feeding, deterrence was calculated as described by Huang and Ho (1998).

$$
\text { Relative growth rate }(\mathrm{RGR})=(\mathrm{A}-\mathrm{B}) /(\mathrm{B} \times 3)
$$

Where: $A$ is the weight of live insects $(\mathrm{mg}) / \mathrm{no}$, of live insects on the third day, $B$ is the original weight of insects $(\mathrm{mg}) /$ original no. of insects.

\section{Relative consumption rate $(\mathrm{RCR})=\mathrm{D} /(\mathrm{B} \times 3)$}

Where: $D$ is biomass ingested $(\mathrm{mg}) /$ no. Of live insects on the third day.

$$
\begin{aligned}
& \text { Efficiency of conversion of ingested food }(\mathrm{ECI})(\%)= \\
& (\mathrm{RGR} / \mathrm{RCR}) \times 100
\end{aligned}
$$

Where: RGR is relative growth rate and RCR is relative consumption rate

Feeding deterrence index $(\mathrm{FDI})(\%)=(\mathrm{C}-\mathrm{T}) \times 100 / \mathrm{C}$

Where: $C$ is the consumption of control disks, and $T$ is the consumption of treated disks, as the control and treated disks were placed in separate vials.

\section{Statistical analysis}

All experiments were arranged in a completely randomized design. Percentage of mortality data analyzed using ANOVA. If there are significant differences in treatment, then the testing will continue to determine the differences between treatments using the LSD (0.05). Median Lethal Concentration (LC50) (concentrations needed to kill $50 \%$ of test insects) was calculated using Probit analysis in the program of SPSS v21 (SPSS Inc., Chicago, IL, United States).

\section{RESULTS AND DISCUSSION}

\section{Chemical constituents of essential oils}

Analysis results of Gas Chromatography-Mass Spectrometry (GC-MS) to five essential oils were resumed in Table 1.

\begin{tabular}{|c|c|c|c|c|}
\hline $\begin{array}{l}\text { Essential } \\
\text { oils }\end{array}$ & No & $\begin{array}{c}\text { Main } \\
\text { constituents }\end{array}$ & $\begin{array}{c}\text { Retention } \\
\text { time }\end{array}$ & $\begin{array}{c}\text { Area } \\
(\%)\end{array}$ \\
\hline C. verum & & $\beta$-Ocimene & 6.573 & 5.01 \\
\hline \multirow[t]{24}{*}{ (Cinnamon) } & 2 & Camphene & 6.853 & 1.52 \\
\hline & 3 & $\beta$-Phellandrene & 7.211 & 0.35 \\
\hline & 4 & $\beta$-Pinene & 7.319 & 2.97 \\
\hline & 5 & 1-Limonene & 8.135 & 1.12 \\
\hline & 6 & Eucalyptol & 8.216 & 5 \\
\hline & 7 & Linalool & 9.224 & 1.72 \\
\hline & 8 & (-)-Alcanfor & 10.205 & 0.35 \\
\hline & 9 & 1-Borneol & 10.527 & 1.28 \\
\hline & 10 & Terpinen-4-ol & 10.667 & 1.14 \\
\hline & & $\alpha$-Terpineol & 10.857 & 3.44 \\
\hline & & Cinnamaldehyde & 12.177 & 35.46 \\
\hline & & D.L-Isobornyl acetate & 12.379 & 3.36 \\
\hline & & Limonene & 13.232 & 0.68 \\
\hline & 15 & Valencene & 13.700 & 0.77 \\
\hline & & $\alpha$-Copaene & 13.770 & 11.95 \\
\hline & 17 & Germacrene a & 13.941 & 0.32 \\
\hline & & trans-caryophyllene & 14.467 & 4.34 \\
\hline & & Cinnamyl acetate & 14.561 & 1.95 \\
\hline & 20 & $\alpha$-Benzopyrone & 14.778 & 1.88 \\
\hline & 21 & Humulene & 14.939 & 1.09 \\
\hline & & $\begin{array}{l}\text { Germacra-1(10).4(15).5- } \\
\text { triene }\end{array}$ & 15.156 & 1.91 \\
\hline & 23 & $\alpha$-Amorphene & 15.451 & 2.05 \\
\hline & 24 & $\delta$-Cadinene & 15.747 & 3.75 \\
\hline & & Unknown constituents & & 6.59 \\
\hline C. hystrix & 1 & d-Sabinene & 6.565 & 0.44 \\
\hline \multirow[t]{3}{*}{ (Kaffir Lime) } & 2 & $\beta$-Linalool & 8.576 & 1.65 \\
\hline & 3 & $\beta$-Citronellal & 9.480 & 86.43 \\
\hline & 4 & $\beta$-Citronellol & 10.634 & 11.48 \\
\hline C. nardus & 1 & $\beta$-Citronellal & 9.37 & 8.09 \\
\hline (Citronella & 2 & $\beta$-Citronellol & 10.551 & 11.65 \\
\hline \multirow[t]{5}{*}{ Grass) } & 3 & Geraniol & 10.987 & 62.83 \\
\hline & 4 & Lavandulyl acetate & 12.883 & 3.05 \\
\hline & 5 & $\begin{array}{l}\text { 4-Pentenamide. 3- } \\
\text { methyl-N-phenyl- }\end{array}$ & 14.468 & 0.84 \\
\hline & 6 & trans-Methylisoeugenol & 14.579 & 9.02 \\
\hline & 7 & Unknown constituents & & 13.54 \\
\hline E. suaveolens & & Limonene & 8.141 & 1.16 \\
\hline \multirow[t]{8}{*}{ (Zodea) } & & Menthofurane & 10.441 & 6.69 \\
\hline & & $\begin{array}{l}\text { p-Mentha-1(7).8(10)- } \\
\text { dien-9-ol }\end{array}$ & 12.388 & 1.7 \\
\hline & 4 & Evodone & 13.258 & 14.01 \\
\hline & 5 & Limonen-10-yl acetate & 14.083 & 6.52 \\
\hline & 6 & Isoledene & 14.371 & 3.14 \\
\hline & 7 & Alloaromadedrene & 14.938 & 1.9 \\
\hline & 8 & Humulene & 17.578 & 3.63 \\
\hline & 9 & Unknown constituents & & 61.25 \\
\hline S. aromaticum & & Eugenol & 13.311 & 41.63 \\
\hline \multirow[t]{2}{*}{ (Clove) } & 2 & trans-Caryophyllene & 14.401 & 46.82 \\
\hline & 3 & Unknown constituents & & 11.55 \\
\hline
\end{tabular}

Table 1. Chemical constituents analysis of essential oils by Gas Chromatography-Mass Spectrometry (GCMS)

The extraction of essential oils by the maceration method showed the composition with varying compounds and amounts. Total compounds for cinnamon, kaffir lime, citronella grass, zodea, and clove were $24,4,6,8$, and 2 compounds, respectively. That compounds, respectively, representing $93.41 \%, 100 \%, 86.46 \%, 38.75$, and $88.45 \%$ of 
the total essential oil. Essential oils of plants may contain hundreds of different constituencies, but certain components will be present in larger quantities (Rajendran and Sriranjini 2008). The main constituents in cinnamon oil were Cinnamaldehyde $(35.46 \%)$, kaffir lime oil was $\beta$ citronellal $(86.43 \%)$, citronella grass oil was geraniol $(62.83 \%)$, zodea oil was evodone $(14.01 \%)$, and clove oil was eugenol $(41.63 \%)$ and trans-caryophyllene $(46.82 \%)$ (Tabel 1). The identified main compound kinds are supported by previous reports. The bark yields of cinnamon essential oil containing cinnamic aldehyde $62.09 \%$ (Kamaliroosta et al. 2012). Beta-citronellal was the major compound of kaffir lime oil, present with $66.85 \%$ (Loh et al. 2011). The major constituent of citronella grass oil was geraniol (55.57\% of total volatiles) (Chanthai et al. 2012). Evodone compound found in leaves organ of zodia plant (Iriani and Yanuastri 2020). The isolated components of clove oil were identified as eugenol (51.51\%) and caryophyllene (36.20\%) (Hossain et al. 2012). The differences in the amount of each compound can be caused by several facts. The chemical composition (chemotype) and biological activity of essential oils distilled from the plants belonging to the same species may vary significantly, depending on the variety of cultivars, environment, elevation, and cultivation methods (Avetisyan et al. 2017).

Based on the results of GC-MS analysis, obtained some of the main compounds of each plant essential oils. The main constituents in cinnamon oil were Cinnamaldehyde (35.46) and $\alpha$-Copaene (11.95\%). For kaffir lime oil, the main constituents were $\beta$-citronellal (86.43\%) and $\beta$ citronellol (11.48\%). Citronella grass oil contained geraniol $(62.83 \%)$ and $\beta$-citronellol $(11.65 \%)$ as the main constituents. Evodone (14.01\%) and menthofurane $(6.69 \%)$ were the main constituents of zodea oil. The analysis of clove oil revealed that eugenol $(41.63 \%)$ and transcaryophyllene $(46.82 \%)$ were the main constituents. The active components showed the toxicity of the insect in the vapor phase could be grouped into five categories, namely, monoterpenoid, cyanohydrins and cyanates, sulfur compounds (dimethyl disulfide, diethyl trisulphide, di-npropyl disulfide, allyl disulfide, diallyl trisulfide, thiosulfinates allyl), alkaloids (Z-asarone) and others (methyl salicylate, benzene derivatives, bornyl acetate, terpinolene). Essential oils contain many volatile, lowmolecular-weight terpenes, and phenolics (Regnault-Roger et al. 2012). The majority of the active ingredients secondary metabolites are issued on plants as chemical defenses against pest organisms (Rajendran and Sriranjini 2008). The monoterpenes are usually one of the important factors for the biological activities of essential oils. Volatile chemical components from plants such as monoterpenes are important bioresources as insect deterrent agents, perhaps due to characteristics of lipophilic chemistry (Aliyu et al. 2015).

\section{Fumigant toxicity}

Five essential oils showed fumigant activity against four stages of $C$. ferrugineus (Table 2).

Table 2. Fumigant effects of five plants extract to mortality on four stages Cryptolestes ferrugineus after $48 \mathrm{~h}$ of exposure*

\begin{tabular}{|c|c|c|c|c|c|}
\hline \multirow{2}{*}{ Essential oils } & \multirow{2}{*}{$\begin{array}{c}\text { Concentration } \\
\text { (ppm) }\end{array}$} & \multicolumn{4}{|c|}{ Percentage of mortality at development stage \pm SE } \\
\hline & & Eggs & Larvae & Pupae & Adults \\
\hline \multirow[t]{5}{*}{ C. verum (Cinnamon) } & 0 & $0.0 \pm 0.0$ & $0.0 \pm 0.0$ & $0.0 \pm 0.0$ & $0.0 \pm 0.0$ \\
\hline & 5 & $21 \pm 3.3 a$ & $7 \pm 1.2 \mathrm{a}$ & $22 \pm 4.1 \mathrm{a}$ & $16 \pm 3.3 \mathrm{a}$ \\
\hline & 10 & $27 \pm 2.6 a$ & $25 \pm 1.6 b$ & $57 \pm 2.0 b$ & $48 \pm 5.2 b$ \\
\hline & 20 & $49 \pm 1.9 b$ & $47 \pm 2.6 c$ & $88 \pm 2.6 c$ & $71 \pm 1.9 \mathrm{c}$ \\
\hline & 40 & $82 \pm 2.0 \mathrm{c}$ & $63 \pm 2.6 \mathrm{~d}$ & $100 \pm 0.0 \mathrm{~d}$ & $86 \pm 2.9 \mathrm{~d}$ \\
\hline \multirow[t]{5}{*}{ C. hystrix (Kaffir Lime) } & 0 & $0.0 \pm 0.0$ & $0.0 \pm 0.0$ & $0.0 \pm 0.0$ & $0.0 \pm 0.0$ \\
\hline & 5 & $20 \pm 2.7 a$ & $10 \pm 1.6 \mathrm{a}$ & $29 \pm 2.5 a$ & $13 \pm 5.4 a$ \\
\hline & 10 & $36 \pm 2.9 b$ & $31 \pm 2.9 b$ & $60 \pm 3.5 b$ & $30 \pm 7.6 b$ \\
\hline & 20 & $74 \pm 2.9 c$ & $58 \pm 3.7 c$ & $90 \pm 2.7 c$ & $68 \pm 4.6 c$ \\
\hline & 40 & $93 \pm 3.0 \mathrm{~d}$ & $77 \pm 2.6 \mathrm{~d}$ & $100 \pm 0.0 \mathrm{~d}$ & $83 \pm 2.0 \mathrm{~d}$ \\
\hline \multirow[t]{5}{*}{ C. nardus (Citronella Grass) } & 0 & $0.0 \pm 0.0$ & $0.0 \pm 0.0$ & $0.0 \pm 0.0$ & $0.0 \pm 0.0$ \\
\hline & 5 & $18 \pm 2 a$ & $13 \pm 2.6 a$ & $34 \pm 2.9 a$ & $12 \pm 2.6 \mathrm{a}$ \\
\hline & 10 & $46 \pm 5.8 b$ & $27 \pm 2.6 b$ & $64 \pm 5.3 b$ & $36 \pm 4.3 b$ \\
\hline & 20 & $80 \pm 2.2 c$ & $48 \pm 2.6 c$ & $78 \pm 4.6 c$ & $69 \pm 2.9 c$ \\
\hline & 40 & $95 \pm 2.2 \mathrm{~d}$ & $67 \pm 3.7 d$ & $97 \pm 2.0 \mathrm{~d}$ & $89 \pm 1.9 \mathrm{~d}$ \\
\hline \multirow[t]{5}{*}{ E. suaveolens (Zodea) } & 0 & $0.0 \pm 0.0$ & $0.0 \pm 0.0$ & $0.0 \pm 0.0$ & $0.0 \pm 0.0$ \\
\hline & 5 & $15 \pm 3.5 a$ & $9 \pm 1.0 \mathrm{a}$ & $17 \pm 3.7 \mathrm{a}$ & $14 \pm 1.9 a$ \\
\hline & 10 & $31 \pm 2.5 b$ & $29 \pm 2.5 b$ & $51 \pm 3.7 b$ & $21 \pm 3.3 \mathrm{a}$ \\
\hline & 20 & $64 \pm 4.3 c$ & $53 \pm 2.6 c$ & $87 \pm 3.7 c$ & $53 \pm 4.6 b$ \\
\hline & 40 & $76 \pm 1.9 \mathrm{~d}$ & $63 \pm 3.4 d$ & $100 \pm 0.0 \mathrm{~d}$ & $72 \pm 3.4 c$ \\
\hline \multirow[t]{5}{*}{ S. aromaticum (Clove) } & 0 & $0.0 \pm 0.0$ & $0.0 \pm 0.0$ & $0.0 \pm 0.0$ & $0.0 \pm 0.0$ \\
\hline & 5 & $17 \pm 3.4 a$ & $13 \pm 2.0 \mathrm{a}$ & $35 \pm 3.2 \mathrm{a}$ & $10 \pm 4.2 \mathrm{a}$ \\
\hline & 10 & $52 \pm 4.1 b$ & $32 \pm 2.6 b$ & $67 \pm 2.0 b$ & $41 \pm 2.9 b$ \\
\hline & 20 & $76 \pm 2.9 c$ & $44 \pm 4.3 c$ & $81 \pm 4.0 c$ & $64 \pm 4.3 c$ \\
\hline & 40 & $87 \pm 2.0 \mathrm{~d}$ & $63 \pm 2.6 \mathrm{~d}$ & $99 \pm 1.0 \mathrm{~d}$ & $91 \pm 1.9 \mathrm{~d}$ \\
\hline
\end{tabular}

Note: * Means within a column followed by the same letters are not significantly different between concentrations ( $\mathrm{p}>0.05)$ in the LSD test. $\mathrm{SE}=$ Standard Error 
The toxic effect of the essential oils is influenced by concentration $(\mathrm{P}<0.05)$. Fumigant activity of the essential oils causes interference in the respiratory system and can increase the activity of sensory nerves are high, leading to death due to the disruption of some insect body systems (Henn and Weinzieri 1989). Fumigant from essential oil could enter either through the cuticle or through the spiracle (Phillips and Appel 2010). The probable reason for the death of insects when exposed to volatiles could be either due to interference in gaseous exchange in respiration or asphyxiation (Michaelraj and Sharma 2006). At the fumigation test to $C$. ferrugineus, the mortality percentage of five essential oils was influenced by the level of concentration and development stage (Table 2). Correa et al. (2015) demonstrated that essential oils of cinnamon and cloves have fumigant activity against pests storedproduct, which could be potent as grain protectants. The results of previous studies, essential oil of kaffir lime (Ikawati et al. 2017), citronella grass (Doumbia et al. 2014), and zodea (Cameron et al. 2016) have toxic properties against certain types of stored pests.

The median lethal concentration or LC50 of essential oils to C.ferrugineus is presented in Table 3 . The smaller the value of LC50, means more toxic the essential oil, and vice versa. Probit analysis of the concentration mortality response of $C$.ferrugineus to essential oils shows that varied between development stages. LC50 of all essential oils for eggs larvae, pupae, and adults respectively, for cinnamon, were $17,24,9$, and 12 ppm, for kaffir lime were $12,17,8$ and $15 \mathrm{ppm}$, however, on citronella grass were 11 , 22,8 , and $14 \mathrm{ppm}$, for zodea were 16, 22, 10 and $20 \mathrm{ppm}$, for clove were $11,24,7$ and 14 ppm. On cinnamon oil, pupae and adults were more susceptible than the eggs and larvae. While the other four types of essential oils, eggs, and pupae were more susceptible than larvae and adults. However, based on statistical analysis of the data did not show significant differences between LC50 values of eggs, larvae, pupae and adults obtained for any of essential oils $(F=0.116$, df $=4, P=0.975 ; F=0.040$, df $=4, P=$ $0.997 ; F=0.014$, df $=4, P=1.000 ; F=0.084$, df $=4, P=$ 0.986).

Essential oils toxicity to the development stages of $C$. ferrugineus is also compared (Table 3). Fumigant activity of essential oils varied according to the development stage. Larvae more resistance compared with other stadia. This results in similar to previous results, in which no fumigant toxicity was observed with the several essential oils on Tribolium castaneum larvae (Stefanazzi et al. 2011), and the most tolerant insect stage was E. kuehniella larva when tested to monoterpenoids (Erler 2005). The lack of fumigant activity on larvae could be due to many reasons. One of which can be caused by an increase of fat amount is stored on the final larval stadium, when fat is synthesized and stored in large quantities (like most insecticides, oils are fat-soluble and therefore may accumulate in fatty tissues in which they are ineffective) (Gillott 2005). For adults in this research were more tolerant than eggs stadia to four kinds of essential oils, only to cinnamon oil adults more susceptible than eggs stadia. Adults were generally susceptible, whereas eggs were either tolerant or highly susceptible depending on insect species and the type of essential oil or component (Rajendran and Sriranjini 2008).

Table 3. Lethal concentration of five plant extracts on four stages of Cryptolestes ferrugineus after a 48-h exposure period

\begin{tabular}{|c|c|c|c|c|c|c|}
\hline Stadia & Essential oils & Regression line equation & $\begin{array}{l}\text { Standard } \\
\text { Error }\end{array}$ & $\mathbf{L C}_{50}(\mathbf{p p m})$ & $\mathrm{LC}_{90}(\mathbf{p p m})$ & $\begin{array}{l}\text { Confidence limit } \\
\text { of } \mathbf{L C}_{50}(\mathrm{ppm})\end{array}$ \\
\hline \multirow[t]{5}{*}{ Eggs } & C. verum & $y=-2.348+1.908 x$ & 0.472 & $16.996 \mathrm{a}$ & 79.775 & $11.697-27.078$ \\
\hline & C. hystrix & $y=-2.816+2.631 x$ & 0.531 & $11.760 \mathrm{a}$ & 36.106 & $8.554-15.677$ \\
\hline & C. nardus & $y=-2.948+2.883 x$ & 0.568 & $10.537 \mathrm{a}$ & 29.329 & $7.727-13.738$ \\
\hline & E. suaveolens & $y=-2.450+2.033 x$ & 0.479 & $16.048 \mathrm{a}$ & 68.538 & $11.171-24.094$ \\
\hline & S. aromaticum & $y=-2.408+2.316 x$ & 0.505 & $10.952 \mathrm{a}$ & 39.154 & $7.431-14.959$ \\
\hline \multirow[t]{5}{*}{ Larvae } & C. verum & $y=-2.674+1.928 x$ & 0.496 & $24.362 \mathrm{a}$ & 112.559 & $16.940-45.451$ \\
\hline & C. hystrix & $y=-2.756+2.224 x$ & 0.497 & $17.362 \mathrm{a}$ & 65.454 & $12.515-25.541$ \\
\hline & C. nardus & $y=-2.348+1.748 x$ & 0.473 & $22.036 \mathrm{a}$ & 119.198 & $14.889-42.461$ \\
\hline & E. suaveolens & $y=-2.429+1.805 x$ & 0.48 & $22.162 \mathrm{a}$ & 113.617 & $15.133-41.320$ \\
\hline & S. aromaticum & $y=-2.109+1.531 x$ & 0.464 & $23.858 \mathrm{a}$ & 164.012 & $15.345-58.815$ \\
\hline \multirow[t]{5}{*}{ Pupae } & C. verum & $y=-3.244+3.460 x$ & 0.7 & $8.660 \mathrm{a}$ & 20.32 & $6.483-10.978$ \\
\hline & C. hystrix & $y=-2.898+3.245 x$ & 0.693 & $7.819 \mathrm{a}$ & 19.415 & $5.588-10.028$ \\
\hline & C. nardus & $y=-1.992+2.268 x$ & 0.543 & $7.559 \mathrm{a}$ & 27.767 & $4.389-10.454$ \\
\hline & E. suaveolens & $y=-3.601+3.683 x$ & 0.715 & $9.501 \mathrm{a}$ & 21.169 & $7.342-11.943$ \\
\hline & S. aromaticum & $y=-2.117+2.475 x$ & 0.582 & $7.169 \mathrm{a}$ & 23.622 & $4.289-9.746$ \\
\hline \multirow[t]{5}{*}{ Adults } & C. verum & $y=-2.445+2.270 x$ & 0.499 & $11.950 \mathrm{a}$ & 43.856 & $8.218-16.488$ \\
\hline & C. hystrix & $y=-2.854+2.435 x$ & 0.507 & $14.867 \mathrm{a}$ & 49.957 & $10.852-20.570$ \\
\hline & C. nardus & $y=-3.040+2.688 x$ & 0.532 & $13.524 \mathrm{a}$ & 40.543 & $10.040-18.060$ \\
\hline & E. suaveolens & $y=-2.595+1.986 x$ & 0.483 & $20.256 a$ & 89.474 & $14.245-33.454$ \\
\hline & S. aromaticum & $y=-3.107+2.746 x$ & 0.542 & $13.530 \mathrm{a}$ & 39.623 & $10.097-17.980$ \\
\hline
\end{tabular}

Note: $* \mathrm{LC}_{50}$ and $\mathrm{LC}_{90}=$ the concentration at which $50 \%$ and $90 \%$ of the insects died. $*$ Means within a column followed by the same superscript letters are not significantly different at $\mathrm{p}>0.05$ in the LSD test 
Some insects have greater sensitivity to chemicals because of their anatomy and physiology (Mewis and Ulrichs 2001). This view is supported by numerous reports, which show great variations in the susceptibility of insects to essential oils, irrespective of size, genera, or species (Michaelraj and Sharma 2006). Authors attribute susceptibility variations that could be caused by cuticular components in stored-product insect species. The cuticle's chemical composition depends on the developmental stage and could influence the effect of chemicals (Balabanidou et al. 2018; Mewis and Ulrichs 2001). The tolerance observed in the larval stage could be due to larger dosages required to kill the insects or due to differences in the metabolism of xenobiotics, depending on the insect stage (Stefanazzi et al. 2011).

\section{Nutritional indices and antifeeding activity}

The flour disks bioassay results are shown in Table 3. Cinnamon, kaffir lime, citronella grass, zodea, and clove essential oil had significantly $(\mathrm{P}<0.05)$ reduce their relative growth, food consumption, and utilization of $C$. ferrugineus adults. All essential oil had no effect on the mortality of $C$. ferrugineus adults. The essential oil of cinnamon was significantly reduced the relative growth rate (RGR) and relative consumption rate (RCR) at concentrations of 2.5, 5, and $10 \mu \mathrm{L} /$ disk and food utilization (ECI) at a concentration of 5 and $10 \mu \mathrm{L} /$ disk. Further, kaffir lime significantly reduced the relative growth rate and food utilization at concentrations of 2.5, 5, and $10 \mu \mathrm{L} /$ disk and relative consumption rate at concentrations of 5 and $10 \mu \mathrm{L} /$ disk. While, for citronella grass, significantly reduced growth in a concentration range of 1.25-10 $\mu \mathrm{L} / \mathrm{disk}$, food consumption at concentrations of 2.5, 5, and $10 \mu \mathrm{L} /$ disk and food utilization at concentrations of $10 \mu \mathrm{L} / \mathrm{disk}$. For zodea oil, significantly reduced growth at concentrations of $2.5,5$, and $10 \mu \mathrm{L} / \mathrm{disk}$, and food consumption and food utilization at concentrations of 5 and $10 \mu \mathrm{L} /$ disk. While, for clove oil, significantly reduced growth and food utilization at concentrations of $2.5,5$ and $10 \mu \mathrm{L} / \mathrm{disk}$, and food consumption at concentrations of 5 and $10 \mu \mathrm{L} / \mathrm{disk}$.

The decrease in RCR due to feeding treatment indicates that the active component of this preparation functions as a primary antifeedant, namely the refusal of food by insects due to the direct nature of the active component before the active component is absorbed by the body (Syahputra et al. 2006). Inhibitory compounds contained in the extract of plants seem to disrupt feeding stimulation signals or to be able to cover (Syahputra et al. 2019). The results of decreasing RGR in treatment was caused not only by a decrease in RCR but also by a decrease in ECI. A low ECI indicates a low digestibility of the feed, which means there is also a disturbance in the digestive process, such as a disturbance in the digestive enzymes of insects (Syahputra et al. 2006).

Table 4. Growth, food consumption, dietary utilization, and mortality of Cryptolestes ferrugineus on flour disks bioassay containing essential

\begin{tabular}{|c|c|c|c|c|c|c|}
\hline Essential oils & $\begin{array}{c}\text { Concentration } \\
(\mu \mathrm{L} / \text { disk })\end{array}$ & $\begin{array}{c}\text { RGR [mg/(mg x } \\
\text { day)] }\end{array}$ & $\begin{array}{c}\text { RCR [mg/(mg x } \\
\text { day)] }\end{array}$ & $\begin{array}{l}\text { ECI } \\
(\%)\end{array}$ & FDI $(\%)$ & $\begin{array}{c}\text { Mortality after } 3 \\
\text { days }(\%)\end{array}$ \\
\hline \multirow[t]{5}{*}{ C. verum (Cinnamon) } & 0 & $0.048 \mathrm{a}$ & $0.567 \mathrm{a}$ & $8.36 \mathrm{a}$ & - & 0 \\
\hline & 1.25 & $0.032 \mathrm{a}$ & $0.506 \mathrm{ab}$ & $6.48 \mathrm{ab}$ & $6.99 a$ & 0 \\
\hline & 2.5 & $0.027 b$ & $0.449 b c$ & $6.22 \mathrm{ab}$ & $11.70 \mathrm{a}$ & 0 \\
\hline & 5 & $0.017 \mathrm{bc}$ & $0.415 b c$ & $4.52 b c$ & $8.16 a$ & 0 \\
\hline & 10 & $0.010 \mathrm{c}$ & $0.386 \mathrm{c}$ & $2.37 \mathrm{c}$ & $4.04 \mathrm{a}$ & 0 \\
\hline C. hystrix (Kaffir & 0 & $0.042 \mathrm{a}$ & $0.330 \mathrm{a}$ & $13.20 \mathrm{a}$ & - & 0 \\
\hline \multirow[t]{4}{*}{ Lime) } & 1.25 & $0.035 \mathrm{a}$ & $0.318 \mathrm{a}$ & $11.39 \mathrm{ab}$ & $7.43 \mathrm{a}$ & 0 \\
\hline & 2.5 & $0.019 b$ & $0.265 \mathrm{ab}$ & $7.30 \mathrm{~b}$ & $15.89 \mathrm{a}$ & 0 \\
\hline & 5 & $0.007 \mathrm{bc}$ & $0.188 b c$ & $4.09 \mathrm{bc}$ & $26.94 \mathrm{ab}$ & 0 \\
\hline & 10 & $0.001 \mathrm{c}$ & $0.120 \mathrm{c}$ & $0.92 \mathrm{c}$ & $37.23 b$ & 0 \\
\hline C. nardus (Citronella & 0 & $0.028 \mathrm{a}$ & $0.134 \mathrm{a}$ & $25.12 \mathrm{a}$ & - & 0 \\
\hline \multirow[t]{4}{*}{ Grass) } & 1.25 & $0.014 b$ & $0.110 \mathrm{ab}$ & $20.31 \mathrm{ab}$ & $19.34 \mathrm{a}$ & 0 \\
\hline & 2.5 & $0.008 b$ & $0.060 \mathrm{bc}$ & $15.00 \mathrm{ab}$ & $27.33 \mathrm{a}$ & 0 \\
\hline & 5 & $0.001 b c$ & $0.047 \mathrm{bc}$ & $1.67 \mathrm{abc}$ & $29.50 \mathrm{a}$ & 2 \\
\hline & 10 & $-0.001 c$ & $0.012 \mathrm{c}$ & $-17.00 \mathrm{c}$ & $58.22 \mathrm{a}$ & 2 \\
\hline E. suaveolens & 0 & $0.042 \mathrm{a}$ & $0.568 \mathrm{a}$ & $7.46 a$ & - & 0 \\
\hline \multirow{4}{*}{ (Zodea) } & 1.25 & $0.035 \mathrm{abc}$ & $0.575 \mathrm{a}$ & $5.98 \mathrm{ab}$ & $-1.49 a$ & 0 \\
\hline & 2.5 & $0.026 b c$ & $0.520 \mathrm{abc}$ & $4.78 \mathrm{ab}$ & $9.72 \mathrm{a}$ & 0 \\
\hline & 5 & $0.019 \mathrm{c}$ & $0.465 b c$ & $4.10 \mathrm{~b}$ & $10.72 \mathrm{a}$ & 0 \\
\hline & 10 & $0.023 \mathrm{c}$ & $0.472 \mathrm{c}$ & $4.95 \mathrm{~b}$ & $0.58 \mathrm{a}$ & 2 \\
\hline S. aromaticum & 0 & $0.033 \mathrm{a}$ & $0.491 \mathrm{a}$ & $6.68 \mathrm{a}$ & - & 0 \\
\hline \multirow[t]{4}{*}{ (Clove) } & 1.25 & $0.022 \mathrm{ab}$ & $0.496 \mathrm{a}$ & $4.10 \mathrm{ab}$ & $0.56 \mathrm{a}$ & 0 \\
\hline & 2.5 & $0.014 b$ & $0.450 \mathrm{ab}$ & $2.94 \mathrm{~b}$ & $9.66 \mathrm{a}$ & 0 \\
\hline & 5 & $0.006 \mathrm{~b}$ & $0.400 \mathrm{~b}$ & $1.51 \mathrm{~b}$ & $11.59 \mathrm{a}$ & 0 \\
\hline & 10 & $0.006 \mathrm{~b}$ & $0.385 b$ & $1.44 \mathrm{~b}$ & $4.59 \mathrm{a}$ & 4 \\
\hline
\end{tabular}

Note: * Within each of essential oils. Means within a column followed by the same letters are not significantly different at $\mathrm{p}>0.05$ in the LSD test. * RGR = relative growth rate; RCR = relative consumption rate; ECI = efficiency of conversion of ingested food; FDI = Feeding deterrence index 
Feeding deterrence indices show that all essential oils had antifeedant action against $C$.ferrugineus in a concentration range of $1.25-10 \mu \mathrm{L} /$ disk (Table 3 ). There is a significant difference between concentration on antifeedant action on kaffir lime oil only, with a $37 \%$ reduction in feeding recorded at a concentration of 10 $\mu \mathrm{L} /$ disk. No post-ingestive toxicity was observed against $C$. ferrugineus showed by mortality percentage (Table 3). The effects of each essential oil on the feeding of $C$. ferrugineus adults were different; however, all essential oil it significantly $(\mathrm{P}<0.05)$ reduced growth rate, food consumption, and utilization. These are indicating that essential oils possess both behavioral effects and postingestive toxicity (Xie et al. 1994), resulting in inhibition of growth by essential oils at higher concentrations. The difference between the antifeedant effects of essential oils may be due to the greater susceptibility of adults to essential oils toxicity. On four essential oils except for kaffir lime oil, concentration level had no significant effects on antifeedant action. For kaffir lime oil showed antifeedant activity with increasing concentrations. However, other levels of concentration have not yet been used for testing the antifeedant action of the chemical against adults for the other four oils. Hence, it is not known whether the concentration-effect antifeedant action. No post-ingestive toxicity for cinnamon and kaffir lime was observed against $C$. ferrugineus, for citronella grass, zodea, and clove was very small, below $5 \%$ (Table 3 ). The lack of toxicity could be due to the combination of physical factors (look like peritrophic matrix) and chemical factors (look like gut redox potential and mixed-function oxidases) that could protect the insect from toxic plant chemicals (Gillott 2005).

In this study, showed that all essential oils have fumigant toxicity to all stage of $C$.ferrugineus, eating inhibitory activity, and affect the nutritional index of $C$. ferrugineus adults. However, further studies are needed for other bioactivities (eating inhibitory activity to $C$.ferrugineus larvae, repellent, progeny production, and effect to enzyme activity that play a role in toxicity process). Other studies for formulation and under bulk storage conditions should be carried out before recommending the large-scale use of these essential oils.

\section{ACKNOWLEDGEMENTS}

Authors gratefully acknowledge Indonesia Toray Science Foundation (ITSF) for financial support.

\section{REFERENCES}

Abbott WS. 1925. A method for computing the effectiveness of an insecticide. J Econ Entomol 18: 265-267.

Aliyu A, Adeyemi M, Abdulkadir I, Dambatta M, Amupitan J, Oyewale A. 2015. Antifeedant activity of Vernonia oocephala against stored product pest Tribolium casteneum (Herbst). Bangladesh J Sci Ind Res 49: 243-248.

Avetisyan A, Markosian A, Petrosyan M, Sahakyan N, Babayan A, Aloyan S, Trchounian A. 2017. Chemical composition and some biological activities of the essential oils from basil Ocimum different cultivars. BMC Complement Altern Med 17: 1-8.

Balabanidou V, Grigoraki L, Vontas J. 2018. Insect cuticle: a critical determinant of insecticide resistance. Curr Opin Insect Sci 27: 68-74.

Boyer S, Zhang H, Lempérière G. 2012. A review of control methods and resistance mechanisms in stored-product insects. Bull Entomol Res 102: 213-229.

Cameron RR, Arinafril M. 2016. Uji bioaktivitas ekstrak daun zodea terhadap hama gudang. Jurnal Agroekoteknologi Trop 5: 222-231.

Campolo O, Giunti G, Russo A, Palmeri V, Zappalà L. 2018. Essential oils in stored product insect pest control. J Food Qual 2018: 1-18.

Chanthai S, Prachakoll S, Ruangviriyachai C, Luthria DL. 2012. Influence of extraction methodologies on the analysis of five major volatile aromatic compounds of Citronella grass (Cymbopogon nardus) and Lemongrass (Cymbopogon citratus) grown in Thailand. J AOAC Int 95: 763-772.

Correa YDCG, Faroni LRA, Haddi K, Oliveira EE, Pereira EJG. 2015. Locomotory and physiological responses induced by clove and cinnamon essential oils in the maize weevil Sitophilus zeamais. Pestic. Biochem. and Physiol 125: 31-37.

Descamps LR, Chopa CS, Ferrero AA. 2011. Activity of Schinus areira (Anacardiaceae) essential oils against the grain storage pest Tribolium castaneum. Nat Prod Commun 6: 887-891.

Doumbia M, Yoboue K, Kouamé LK, Coffi K, Kra DK, Kwadjo KE, Dagnogo M. 2014. Toxicity of Cymbopogon nardus (Glumales: Poaceae) against four stored food products insect pests. Int J Farming Alli Sci 3: 903-909.

Erler F. 2005. Fumigant activity of six monoterpenoids from aromatic plants in Turkey against the two stored-product pests confused Flour beetle, Tribolium confusum, and Mediterranean flour moth, Ephestia kuehniella. J Plant Dis Prot 112: 602-611.

Germinara GS, Di Stefano MG, De Acutis L, Pati S, Delfine S, De Cristofaro A, Rotundo G. 2017. Bioactivities of Lavandula angustifolia essential oil against the stored grain pest Sitophilus granarius. Bull Insectology 70: 129-138.

Gillott C. 2005. Entomology 3rd edition. Springer, Dordrecht.

Hasan MM, Aikins MJ, Schilling MW, Phillips TW, Mahroof R. 2020. Comparison of methyl bromide and phosphine for fumigation of Necrobia rufipes (Coleoptera: Cleridae) and Tyrophagus putrescentiae (Sarcoptiformes: Acaridae), pests of high-value stored products. J Econ Entomol 113: 1008-1014.

Henn T, Weinzierl R. 1989. Botanical insecticides and insecticidal soaps/1296. Alternatives in insect management.

Hossain MA, Al-Hashmi, RA, Weli AM, Al-Riyami Q, Al-Sabahib JN. 2012. Constituents of the essential oil from different brands of Syzygium caryophyllatum L by gas chromatography-mass spectrometry. Asian Pac J Trop Biomed 2: 1446-1449.

Huang Y, Ho SH. 1998. Toxicity and antifeedant activity of cinnamaldehyde against the grain storage insects, Tribolium castaneum (Herbst) and Sitophilus zeamais Motsch. J. Stored Prod. Res. 34: 11-17.

Ikawati S, Dhuha MS, Himawan, T. 2017. Bioactivity of Citrus Hystrix D.C. Leaf Extract Against Cigarette Beetle Lasioderma Serricorne (F.). J Trop Life Sci 7: 189-196.

Iriani F, Yanuastri PW. 2020. Diversity and phytochemistry analysis in zodia plant organs (Evodia suaveolens). In IOP Conference Series: Earth and Environmental Science 458 012019: 1-6.

Jagadeesan R, Collins PJ, Nayak MK, Schlipalius DI, Ebert PR. 2016. Genetic characterization of field-evolved resistance to phosphine in the rusty grain beetle, Cryptolestes ferrugineus (Laemophloeidae: Coleoptera). Pestic Biochem Physiol 127: 67-75.

Kamaliroosta L, Gharachorloo M, Kamaliroosta Z. 2012. Extraction of cinnamon essential oil and identification of its chemical compounds. J Med Plants Res 6: 609-614.

Kiran S, Kujur A, Patel L, Ramalakshmi K, Prakash B. 2017. Assessment of toxicity and biochemical mechanisms underlying the insecticidal activity of chemically characterized Boswellia carterii essential oil against insect pest of legume seeds. Pestic Biochem Physiol 139: 1723.

Loh FS, Awang RM, Omar D, Rahmani M. 2011. Insecticidal properties of Citrus hystrix DC leaves essential oil against Spodoptera litura Fabricius. J Med Plants Res 5: 3739-3744.

Mewis I, Ulrichs C. 2001. Action of amorphous diatomaceous earth against different stages of the stored product pests Tribolium 
confusum, Tenebrio molitor, Sitophilus granarius and Plodia interpunctella. J Stored Prod Res 37: 153-164.

Michaelraj S, Sharma RK. 2006. Fumigant toxicity of neem formulations against Sitophilus oryzae and Rhyzopertha dominica. J Agric Technol 2: 1-16.

Phillips AK, Appel AG. 2010. Fumigant toxicity of essential oils to the German cockroach. J Econ Entomol 103: 781-790.

Rajendran S, Sriranjini V. 2008. Plant products as fumigants for storedproduct insect control. J Stored Prod Res 44: 126-135.

Regnault-Roger C, Vincent C, Arnason JT. 2012. Essential oils in insect control: low-risk products in a high-stakes world. Annu Rev Entomol 57: 405-424.

Stefanazzi N, Stadler T, Ferrero A. 2011. Composition and toxic, repellent and feeding deterrent activity of essential oils against the stored-grain pests Tribolium castaneum (Coleoptera: Tenebrionidae) and Sitophilus oryzae (Coleoptera: Curculionidae). Pest Manag Sci 67: 639-646.
Syahputra E, Prijono D, Dadang D, Manuwoto S, Darusman LK. 2006 Physiological response of Crocidolomia pavonana to the Calophyllum soulattri active fraction. Hayati 13: 7-12.

Syahputra E, Hernowo K, Riko R. 2019. Effect of Castanopsis megacarpa extract on mortality, longevity development and feeding of Crocidolomia pavonana larvae. Agrivita 41: 537-547.

Tay WT, Beckett SJ, De Barro PJ. 2016. Phosphine resistance in Australian Cryptolestes species (Coleoptera: Laemophloeidae): perspectives from mitochondrial DNA cytochrome oxidase I analysis. Pest Manag Sci 72: 1250-1259.

Upadhyay R. 2010. Essential oils: anti-microbial, antihelminthic, antiviral, anticancer and anti-insect properties. J Appl Biosci 36: 1-22.

Xie YS, Isman MB, Gunning P, MacKinnon S, Arnason JT, Taylor DR, Sanchez P, Hasbun C, Towers GHN. 1994. Biological activity of extracts of Trichilia species and the Limonoid hirtin against Lepidopteran larvae. Biochem Syst Ecol 22: 129-136. 